DOI: 10.17516/1997-1370-0717

УДК 796.015.622.4

\title{
Improving of Special Physical Fitness and Workability of Female Police Cadets
}

\author{
Aleksander Yu. Osipova,b,c, Vladimir I. Lyakh \\ Vladimir M. Guralev', Tatyana I. Ratmanskayaa, \\ Mikhail D. Kudryavtsever,cd and Roman S. Nagovitsyn ${ }^{\mathrm{e} *}$ \\ a Siberian Federal University \\ Krasnoyarsk, Russian Federation \\ ${ }^{b}$ Krasnoyarsk State Medical University \\ named after Professor V.F. Voino-Yasenetsky \\ Krasnoyarsk, Russian Federation \\ 'Siberian Law Institute of the Ministry of Internal Affairs \\ of the Russian Federation Krasnoyarsk, Russian Federation \\ ${ }^{d}$ Siberian State University of Science and Technology \\ Krasnoyarsk, Russian Federation \\ ${ }^{e}$ Glazov State Pedagogical Institute named after V.G. Korolenko \\ Glazov, Russian Federation \\ ${ }^{f}$ Krakow University of Physical Education \\ Krakow, Poland
}

Received 23.10.2020, received in revised form 11.01.2021, accepted 08.02.2021

\begin{abstract}
The importance of evaluating the physical fitness of future police officers cannot be underestimated. Ideal physical training program must include targeting aerobic capacity, anaerobic power, muscular strength and endurance. The aim of the study: investigate the impact of two additional supervised 16-week physical fitness training programs (mixed (jumping + strength endurance) workout and CrossFit training) aimed at female police cadets.

Participants: relatively healthy young female $(\mathrm{n}=28)$ - cadets had similar indicators of physical fitness and workability. Total time of physical training - 64 hours during 16 weeks (basic workouts -48 hours, additional workouts -16 hours). Group 1 ( $n=14)$ practiced additional CrossFit training. Group $2(\mathrm{n}=14)$ practiced mixed additional workout (jumping + strength endurance). Tests used to evaluate the physical fitness and workability were the following: Push-Up test, Plank test, Running test, Burpee test, Step test (PWC170), test with 30 throws.
\end{abstract}

\footnotetext{
(C) Siberian Federal University. All rights reserved

* Corresponding author E-mail address: ale44132272@yandex.ru, gural100@mail.ru, tanyabaulina@rambler.ru, kumid@yandex.ru, gto18@mail.ru, vladimir.lyakh@awf.krakow.pl

ORCID: 0000-0002-2277-4467 (Osipov); 0000-0001-6257-0488 (Lyakh); 0000-0002-1270-6540 (Guralev); 0000-0001-95441674 (Ratmanskaya); 0000-0002-2432-1699 (Kudryavtsev); 0000-0003-4471-0875 (Nagovitsyn)
} 
The overall positive dynamics of study results shows an increase of workability for all study participants. A reliable $(\mathrm{p} \leq 0.05)$ advantage of participants (group 2) in testing workability results (Burpee test and PWC170) was found.

Experts agree that the most effective physical training programs for cadets and police officers will be combinations of intensive cardiorespiratory and strength workout. A positive impact of additional mixed (jumping + strength endurance) workout on the workability of female cadets was found. Such functional workout can be an effective alternative to CrossFit training in physical training curriculum of female police cadets.

Keywords: female cadets, physical training (PT), CrossFit, workability, mixed workout.

Research area: theory and methodology of physical education, sports training, healthimproving and adaptive physical culture.

Citation: Osipov, A. Yu., Lyakh, V.I., Guralev, V.M., Ratmanskaya, T.I., Kudryavtsev, M.D., Nagovitsyn, R.S. (2021). Improving of special physical fitness and workability of female police cadets. J. Sib. Fed. Univ. Humanit. Soc. Sci., 14(2), 257-265. DOI: 10.17516/1997-1370-0717.

\title{
Повышение специальной физической подготовленности
}

\section{и работоспособности женщин-курсантов полиции}

\author{
А.Ю. Осипов ${ }^{\text {, б, в, В.И. Лях }}$, В.М. Гуралев ${ }^{\text {, }}$ \\ Т.И. Ратманская ${ }^{a}$ М.Д. Кудрявцев ${ }^{a, в, г, ~ Р . С . ~ Н а г о в и ц ы н ~}$ \\ ${ }^{a}$ Сибирский федеральный университет \\ Российская Федерачия, Красноярск

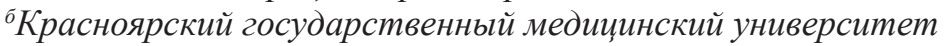 \\ имени профессора В. Ф. Войно-Ясенецкого МЗ РФ \\ Российская Федерачия, Красноярск \\ ${ }^{6}$ Сибирский юридический институт МВД России \\ Российская Федерачия, Красноярск \\ ${ }^{2}$ Сибирский государственный университет науки \\ и технологий имени М. Ф. Решетнева \\ Российская Федерация, Красноярск \\ ¿Глазовский государственный педагогический \\ институт имени В.Г. Короленко \\ Российская Федерачия, Глазов \\ е Университет физического воспитания \\ Польша, Краков
}

\begin{abstract}
Аннотация. Важность оценки физической подготовленности будущих сотрудников полиции нельзя недооценивать. Идеальная программа физической подготовки должна включать в себя целенаправленную аэробную нагрузку, анаэробную нагрузку, тренировки мышечной силы и выносливости. Цель исследования: изучить влияние двух дополнительных контролируемых 16-недельных программ физической подготовки (смешанная тренировка (прыжки + силовая выносливость) и кроссфит-тренировка) на женщин-курсантов полиции.
\end{abstract}


Участники: относительно здоровые молодые девушки $(\mathrm{n}=28)$ - курсанты имели сходные показатели физической подготовленности и работоспособности. Общий объем времени физической подготовки - 64 часа в течение 16 недель (основные тренировки - 48 часов, дополнительные тренировки - 16 часов). Группа 1 (n=14) практиковала дополнительную тренировку по кроссфиту. Группа 2 (n=14) практиковала смешанную дополнительную тренировку (прыжки + силовая выносливость). Тесты для оценки физической подготовленности и работоспособности: отжимания, планка, бег, упражнения бурпи, степ-тест (PWC170), тест с 30 бросками.

Общая положительная динамика результатов исследования свидетельствует о повышении работоспособности всех участниц исследования. Установлено достоверное $(\mathrm{P} \leq 0,05)$ преимущество участниц $(2-я$ группа) в результатах тестирования работоспособности (упражнения бурпи и $\mathrm{PWC170).}$

Специалисты сходятся во мнении, что наиболее эффективными программами физической подготовки курсантов и сотрудников полиции будут сочетания интенсивных кардиореспираторных и силовых тренировок. Установлено положительное влияние дополнительной смешанной тренировки (прыжки + силовая выносливость) на работоспособность женщин-курсантов. Такая функциональная тренировка может стать эффективной альтернативой кроссфиту в программе физической подготовки женщин- курсантов - кадров для полиции.

Ключевые слова: женщины-курсанты, физическая подготовка (РТ), кроссфит, работоспособность, смешанная тренировка.

Научная специальность: 13.00.04 - теория и методика физического воспитания, спортивной тренировки, оздоровительной и адаптивной физической культуры.

\section{Introduction}

Military and police officers require speed, strength, agility, and endurance training for the physical preparation of their job. Physical fitness of a police officers is an essential component of being prepared to do critical tasks, including pursuing fleeing subjects, controlling those resisting arrest, grappling, and handcuffing, as well as crowd control (Crawley et al., 2016). Police officers reported that cardiovascular and muscular endurance were the two physical abilities most required in patrolling duties. Hence, developing physical fitness is an essential component of trainees' PT (Kukić et al., 2019). Studies have found that police cadets' fitness can be improved through a good PT program (Dimitrijević, et al., 2014). Crawley et al. point to an existing gap in the scientific literature, specifically authors do not focus on police cadet physical preparedness and the outcomes of physical training (Crawley et al., 2016).

Cocke et al. indicate that regardless of original format, PT programs can improve the fitness of police cadets, but training program that incorporate various strength and endurance exercises tend to be more effective (Cocke, Dawes, \& Orr, 2016). The importance for improvement or maintenance of aerobic endurance of police cadets at certain level lies in facts that it has been one of the main indicators of performance-related and health-related physical fitness (Kukić et al., 2019). Ideal exercise programming should train future police officers specifically for the movements they will require in their daily tasks. This would include targeting aerobic capacity, anaerobic power, muscular strength, endurance and flexibility (Crawley et al., 2016).

However, not all PT programs that are effective for male police officers will be equally effective for female police officers. Lockie et al. state that female cadets will generally be less physically fit. Training staff should ideally implement individualized fitness programmes (Lockie et al., 2020). Losty et al. findings highlight the need to develop special fitness pro- 
grammes that target female cadets specifically (Losty, Williams, \& Gossman, 2016).

The solution to this problem is the successful adaptation of the modern techniques of intensive functional workout in PT curriculum of the cadets and military students (Kudryavtsev et al., 2018). Kolomiitseva et al. suggest using the CrossFit training program in PT curriculum of cadets (Kolomiitseva et al., 2020). CrossFit is recognized as one of the fastest growing high-intensity functional training modes in the world. CrossFit training routines involve exercises using large groups of muscles, high number of repetitions, fast execution speed and short recovery periods (Maia et al., 2019). CrossFit training modality presents wide cardiorespiratory and neuromuscular adaptations, ranging from improvements in aerobic capacity to pure manifestations of strength (Barbieri et al., 2019). Experts recommend to use CrossFit training to increase special physical fitness (strength endurance) of professional athletes practicing martial arts: judo (Osipov et al., 2018) and combat sambo (Osipov et al., 2017). Various types of CrossFit training are used in PT practice of police and military cadets. Galimova et al. remark that high-intensive CrossFit workout for 20 minutes ( 3 times a week) has a positive impact on the cardiorespiratory system (functional capacities) and workability of cadets (Galimova et al., 2018).

Scientists also point that CrossFit training has more significant advantages than interval (circular) training session (Pryimakov et al., 2019). Yet, scientific data regarding the practice of CrossFit is sparse. The current scientific literature related to CrossFit has few studies with high level of evidence (Claudino et al., 2018). It is well known that CrossFit training programs are associated with a high level of muscle power, strength endurance and good technique as regards performing training exercises. Various injury risks in CrossFit training are quite likely to happen. Nowadays, the issue of increasing the overall effectiveness of workout programs, physical fitness, as well as reducing the risk of injury in practitioners' are undoubtedly topical (Grigor'ev \& Semenova, 2020).

Experts suggest using structured aerobic and strength workouts or a combination of them to increase the physical fitness of cadets. Kukić et al. show that relatively simple additional aerobic fitness training over of 12 weeks, two times per week, could provide meaningful changes in aerobic endurance of female police cadets (Kukić et al., 2019). Cesanelli et al. demonstrate that structured strength sessions can be incorporated in a standard training program influencing endurance performance of athletes positively (Cesanelli et al., 2019). Cardiorespiratory endurance and strength abilities are the basic components of physical fitness that contribute to significant health benefits (Osipov et al., 2020). Despite the unequivocal effectiveness of cardiorespiratory endurance and resistance training, the main factors that discourage individuals from pursuing these types of exercise are the considerable length of training sessions. High-intensity circuit training that relies on body mass for resistance appears to be an effective solution for cardiorespiratory and resistance training (Podstawski et al., 2019). There is scientific evidence of a positive impact of high-intensive jumping workouts on cardiorespiratory fitness and strength endurance of females (Osipov et al., 2020). A short high-intensity specific speed-jumping training program could prove beneficial when intentionally used in the high-intensity training regime to increase explosive power and response time (Mackala et al., 2019).

It is essential to obtain an accurate baseline of existing performance levels to both develop and assess an effective PT program for female cadets. Taking this into account the authors proposed to conduct a comparative analysis of the impact of two different PT programs on the physical fitness and workability female cadets. One PT program consisted of additional CrossFit workouts; the other PT program consisted of additional mixed (jumping + strength endurance) workouts. It was hypothesized that the PT curriculums utilized in this study would have a significant positive effect on the physical workability of female police cadets.

The aim of the study is to investigate the impact of two additional supervised 16-week physical fitness training programs (mixed (jumping + strength endurance) workout and CrossFit training) on female cadets. 


\section{Material \& methods}

\section{Participants}

Relatively healthy young female $(\mathrm{n}=28)$ police cadets of the Siberian Law Institute of the MIA of Russia. The female cadets' average age $-18.64 \pm 0.33$ years. Average height of participants $-164.72 \pm 9.46 \mathrm{sm}$. Average body weight of participants $-55.29 \pm 4.37 \mathrm{~kg}$. All females had similar indicators of physical fitness and workability. All female cadets gave their consent to participate in our study. The study was approved by experts' commission of the Siberian Law Institute of the MIA of Russia.

\section{The research design}

We randomly divided all participants into equal groups in the study beginning (group 1 $\mathrm{n}=14$, and group $2-\mathrm{n}=14$ ). Both groups practiced PT curriculum for 16 weeks (September December). Amount of PT classes totalled 48 hours. About 50 percent of total training time was devoted to physical fitness: development of muscle strength, speed and aerobic endurance. Remaining training time was devoted to studying combat fighting and wrestling techniques. The overall structure of PT classes consisted of a warm-up session (20 min), main PT session (50 min) and final part session $(20 \mathrm{~min})$. All study participants had an additional PT practice -16 hours (one additional training session per week). The total amount of each additional PT session was 60 minutes.

Female cadets (group 1) practiced CrossFit training in additional PT workout (1 training session per week). Each PT session lasted 60 minutes. Each CrossFit training session included warm-up (15 minutes) and next movements: 15 push-ups; 15 back squats using weights (20 kg); 20 butterfly sit-ups; 10 burpee; 10 bench press using weights (15 kg); 20 lunge hops; 15 triceps dip; 10 box jumps (box height $-40 \mathrm{~cm}$ ). Females completed 6 training laps with a rest period of 2 minutes after each training lap.

Female cadets (group 2) practiced special workouts in additional PT session (2 training session per week). Each PT session lasted 30 minutes. Each special workout session included warm-up (10 minutes) and next movements: intensive jumps (alternately with the right leg then the left leg) - 1 minute; push-ups (both hands on the step) - 30 seconds; intensive jumping up with both feet - 1 minute; push-ups (both feet on the step) -30 seconds; straight squats -2 minutes; burpee - 30 seconds; intensive steps using weights (dumbbells $-5 \mathrm{~kg}$ ) -2 minutes; butterfly sit-ups - 30 seconds; intensive jumping up with both feet -1 minute. Participants completed 2 training laps with a rest period of 2 minutes after first training lap. Combined step platform Proxima Fitness FT-STR (China) used in our study. The height of the bench is $25 \mathrm{~cm}$.

To assess the physical fitness and workability of participants special we used tests.

Running test $(2000 \mathrm{~m})$. All female cadets had to run a distance of 2000 meters without slowing down to stepping, walking or stopping before finish. The total running time was recorded.

Burpee test. All female cadets performed a 3-minute burpee test according to the method of Podstawski (Podstawski et al., 2019). Female cadets were instructed on how to perform the burpee test correctly. The test was preceded by an active warm-up (not less then 10 minutes). Cadets' strength endurance was evaluated based on the number of burpee cycles completed in 3 minutes.

Step test (PWC170). All participants performed 2 physical step loads $(5$ minutes each load) with a rest interval of 3 minutes between loads. Participants performed ascents to the step platform (height of step platform was 30 $\mathrm{cm})$. The rate of ascent to the step platform is at least 20 ascents at the first step load and 30 ascents at the second step load. Heart rate parameters were determined within 10 seconds after each test load. Evaluation of cadetsэ workability indicators was carried out using the recommendations of N. Graevskaia. The following Step test (PWC170) indicators are proposed: 14 or less - low level, 15-16 - below average level, 17-18 - average level, 19-20 - above average level, 21-22 - high level of assessment (Graevskaia \& Dolmatova, 2004).

Push-Up test. The Push-Up test was performed according to standard procedure. Cadet's torso was lowered by bending the elbow joints to 90 degrees of flexion in a continuous motion. Females performed as many repetitions as possible using maximum speed 
throughout the test for muscular endurance. The testing time for female cadets is $60 \mathrm{sec}-$ onds. Total number of push-ups was recorded continuously in our study.

Plank test. For the plank position, cadets' feet were placed hip width apart, with the ankles at $90^{\circ}$, knees straight, and pelvis tilted into a neutral position to engage the core. The elbows were bent to $90^{\circ}$ and placed directly below the shoulders with the back flat. The whole exercise was recorded continuously.

Test with 30 throws. A test with 30 throws to evaluate the participants' special physical fitness level. All female cadets completed 30 judo throws - the ippon seoi nage at a fast pace. Each participant applied throws in the left natural posture (15 throws) and the right natural posture (15 throws). All 30 throws were recorded continuously.

\section{Statistical analysis}

Statistical processing of the study results was carried out using SPSS Statistics 17.0. The reliability of differences in the study results was determined using repeated measures analysis of variance (ANOVA). A $p$ value of $\leq 0.05$ was considered statistically significant.

\section{Results}

There were no significant differences in test results of female cadet groups at the study beginning. The cadets' workability indicators
(PWC170) were on average level. The overall positive dynamics of increase in testing results was found in all study participants at the study ending. We can prove the positive impact of two supervised 16-week physical fitness training programmes on female cadets. Significant differences in some test cases for female cadets were found at the study ending. A reliable $(p \leq 0.05)$ advantage of female cadets (group 2) in testing workability results (Burpee test) and (PWC170) was found. The cadets' workability indicators (PWC170) show positive dynamics of improvement from an average to a good level. There were no significant differences in the results in the other test cases. Total testing results of female cadet groups are presented in Table 1.

\section{Discussion}

Scientific reviews provide summary information that intervention studies are needed to promote and incorporate $\mathrm{PT}$ programs related to improvement or maintenance of physical fitness in police officers, which would result in health benefits and specifically improvement in performance of specific tasks of daily police work (Marins, David, \& Del Vecchio, 2019). Our study revealed the positive impact of two additional supervised 16-week physical fitness training programs (mixed (jumping + strength endurance) workout and CrossFit training) on physical fitness and workability

Table 1. The overall testing results of study participants

\begin{tabular}{|c|c|c|c|c|c|c|}
\hline & \multicolumn{3}{|c|}{ September (study beginning) } & \multicolumn{3}{c|}{ December (study ending) } \\
\hline Tests & Group 1 (n=14) & Group 2 (n=14) & $\mathrm{p}=$ & Group 1 (n=14) & Group 2 (n=14) & $\mathrm{p}=$ \\
\hline $\begin{array}{c}\text { Push-Up } \\
\text { (counting) }\end{array}$ & $17.42 \pm 3.29$ & $17.31 \pm 4.36$ & 0.871945 & $20.69 \pm 4.32$ & $19.73 \pm 4.25$ & 0.187479 \\
\hline $\begin{array}{c}\text { Plank } \\
\text { (time) }\end{array}$ & $1.36 \pm 0.34$ & $1.32 \pm 0.29$ & 0.982629 & $1.45 \pm 0.21$ & $1.53 \pm 0.24$ & 0.136513 \\
\hline $\begin{array}{c}\text { Burpee } \\
\text { (counting) }\end{array}$ & $42.57 \pm 6.41$ & $40.62 \pm 5.38$ & 0.298793 & $48.06 \pm 5.44$ & $50.49 \pm 5.37$ & $0.041865^{*}$ \\
\hline $\begin{array}{c}\text { Running } \\
\text { (time) }\end{array}$ & $10.18 \pm 0.34$ & $10.25 \pm 0.31$ & 0.358332 & $10.07 \pm 0.23$ & $10.10 \pm 0.26$ & 0.823378 \\
\hline $\begin{array}{c}\text { Step test } \\
\text { (PWC }\end{array}$ ) & $17.53 \pm 0.29$ & $17.47 \pm 0.22$ & 0.332236 & $18.44 \pm 0.31$ & $18.58 \pm 0.27$ & $0.024604^{*}$ \\
\hline $\begin{array}{c}30 \text { throws } \\
\text { (time) }\end{array}$ & $2.03 \pm 0.18$ & $2.05 \pm 0.21$ & 0.604269 & $1.54 \pm 0.17$ & $1.51 \pm 0.15$ & 0.378479 \\
\hline
\end{tabular}

Note - reliability of differences: ${ }^{*}-p \leqslant 0.05$. 
female cadets. Experts from CIS point to the advantage of using different CrossFit training programs in PT practice of future police officers (Kolomiitseva et al., 2020; Pryimakov et al., 2019; Galimova et al., 2018). Nevertheless, in our opinion, these scientific data do not have a high level of evidence. Some studies do not describe the methodology (Galimova et al., 2018), evidence-based statistics (Kokorev, Vyprikov, Bodrov, 2018), while other studies do not have requirements for sufficient number and physical fitness of participants. Some scientists have conducted studies with very few participants (less than 10 participants), which reduces the level of evidence (Pryimakov et al., 2019). Participants in our study had similar indicators of age, height, weight, and physical fitness to increase the level of evidence. It was found that the positive impact of CrossFit training on such participants does not significantly differ from the impact of mixed (jumping + strength endurance) functional workouts. Moreover, mixed workouts had a higher positive impact on some workability indicators of female cadets.

Podstawski et al. presented data on the assessment of the strength endurance and workability (Burpee test) of similar age females practiced standard PE programmes. Most of females showed an average level of strength endurance by completing 36-50 burpee cycles (Podstawski et al., 2019). Female cadets (group 2) who practiced mixed workout showed a positive dynamics of workability increase by completing $50.49 \pm 5.37$ burpee cycles in the study ending. Females (group 1) who practiced crossfit training were able by completing only $48.06 \pm 5.44$ burpee cycles.

Barbieri et al. reveal that CrossFit programmes did not present higher values than other individual functional training programmes for the aerobic capacity and maximum power (Barbieri et al., 2019). Our research shows the more significant $(\mathrm{p} \leq 0.05)$ positive impact of mixed workouts on some indicators of strength endurance (Burpee test) and workability (PWC170) of female cadets compared to CrossFit training. It can be assumed that the optimal choice of exercises and workout intensity will be the determining factor for in- creasing the workability and physical fitness of practitioners.

Kudryavtsev et al. indicate that the purposeful use of special exercises (Burpee) effectively increases speed-strength and functional abilities of the future police officers in a relatively short period of time - 4-5 weeks (Kudryavtsev et al., 2018). Kolomiitseva et al. indicate that using a 12-week CrossFit program was a significant improvement in the physical fitness of cadets (Kolomiitseva et al., 2020). However, Crawley et al. point that the number of individual parameters of physical fitness of cadets showed evidence of improvement in the first 8 weeks, whereas none of the variables showed significant improvement in the second 8 weeks of a supervised 16 -week physical fitness training program on police cadets. Some modifications could be made to increase overall effectiveness of cadet physical training specifically after the 8-week mark (Crawley et al., 2016). Highly effective PT curriculum be highly important for police cadets - future police officers (Koropanovski et al., 2020). Therefore, optimal PT programmes (functional workout) for police cadets should have a duration of 16 weeks or more. It was found that the use of structured mixed (jumping + strength endurance) workouts has a significant positive impact on the physical fitness of female cadets. According to the authors, similar functional workouts of sufficient duration (16 weeks or more) can exert a stable positive impact on police cadets resulting in an increase in their physical fitness.

\section{Conclusions}

Physical fitness of police officers is an essential component of being prepared to do professional tasks. Police officers reported that cardio-vascular and muscular endurance were the two most required physical abilities. Most experts agree that the most effective PT programmes for cadets and police officers will be combinations of intensive cardiorespiratory and strength workout. A positive impact of two supervised 16-week physical fitness training programs (additional mixed (jumping + strength endurance) workout and CrossFit training) on female cadets was found in our study. Female 
cadets who practiced mixed workouts showed higher results in workability tests: Burpee and PWC170 compared to female cadets who practiced CrossFit. Similar functional workout can be an effective alternative to CrossFit training in PT practice of female police cadets.

\section{Limitations}

The authors tried to avoid possible study limitations related to the participants' number, age, and physical fitness of all participants. However, there were some difficulties with matching up a sufficient number of similar par- ticipants in the females group. Further study with a large number of female participants is needed.

\section{Acknowledgements}

We would like to thank the personnel of Siberian Law Institute of the Ministry of Internal Affair of Russia and all female cadets who participated in the study.

\section{Conflicts of interest}

The authors declare that there is no conflict of interest.

\section{References}

Barbieri, J., Figueiredo, G., Castano, L., Guimaraes, P., Ferreira, R., Ahmadi, S., Gaspari, A., \& De Moraes, A. (2019). A Comparison of Cardiorespiratory Responses Between CrossFit ${ }^{\circledR}$ Practitioners and Recreationally Trained Individual. In Journal of Physical Education and Sport, 19(3), 1606-1611. doi:10.7752/ jpes.2019.03233

Cesanelli, L., Vici, G., Camilletti, D., Ceci, R., Belli, L., \& Polzonetti, V. (2019). Impact of 24 Weeks of Strength Training Coupled to Endurance Training on Endurance Performance (HERO Dolomites 2019). In Journal of Human Sport and Exercise, 14(5proc), S2410-S2418. doi:10.14198/ jhse.2019.14.Proc5.56

Claudino, J., Gabbett, T., Bourgeois, F., Sa Souza, H., Miranda, R., Mezêncio, B., Soncin, R., Serrão, J. (2018). CrossFit Overview: Systematic Review and Meta-Analysis. In Sports Med - Open, 4, 11. doi:10.1186/ s40798-018-0124-5

Cocke, C., Dawes, J., \& Orr, R. (2016). The Use of 2 Conditioning Programs and the Fitness Characteristics of Police Academy Cadets. In Journal of Athletic Training, 51(11), 887-896. doi:10.4085/1062-605051.8 .06

Crawley, A., Sherman, R., Crawley, W., \& Cosio-Lima, L. (2016). Physical Fitness of Police Academy Cadets: Baseline Characteristics and Changes During a 16-Week Academy. In Journal of Strength and Conditioning Research, 30(5), 1416-1424. doi:10.1519/JSC.0000000000001229

Dimitrijević, R., Koropanovski, N., Dopsaj, M., Vučković, G., \& Janković, R. (2014). The Influence of Different Physical Education Programs on Police Students' Physical Abilities. In Policing, 37(4), 794-808.

Galimova A., Kudryavtsev M., Galimov G., Dagbaev B., Doroshenko S., Arutyunyan T., \& Smirnova L. (2018). Functional Training as an Effective Way for Adaptation of the Military Students and Students of Educational Institutions in the System of the Ministry of Internal Affairs of the Russian Federation. In Human. Sport. Medicine, 18(2).119-125. doi:10.14529/hsm180211

Graevskaia, N., \& Dolmatova, T. (2004). Sportivnaia meditsina [Sports medicine]. Moscow: Soviet sport.

Grigor'ev P., \& Semenova, G. (2020). Functional Movement Screening as a Means to Reduce Injuries in Fitness. In Human. Sport. Medicine, 20(1), 114-122. doi:10.14529/hsm200114

Kokorev, D., Vyprikov, D., \& Bodrov, I. (2018). Adapted Version of Multisport CrossFit System for Academic Physical Education Service. In Teoriia i Praktika Fizicheskoi Kultury [Theory and Practice of Physical Education], 8, 35-37.

Kolomiitseva, O., Prykhodko, I., Prikhodko, A., Anatskyi, R., Turchynov, A., Fishev, S., Hunbina, S., \& Garkavyi, O. (2020). Efficiency of Physical Education of University Students Based on the Motivation Choice of the CrossFit Program. In Physical Activity Review, 8(1), 26-38. doi:10.16926/par.2020.08.04 
Koropanovski, N., Kukić, F., Dimitrijević, R., Dawes, J., Lockie, R., \& Dopsaj, M. (2020). Impact of Physical Fitness on Recruitment and its Association to Study Outcomes of Police Students. In South African Journal for Research in Sport, Physical Education and Recreation, 42(1), 23-34

Kudryavtsev, M., Osipov, A., Kokova, E., Kopylov, Y., Iermakov, S., Zhavner, T., Vapaeva, A., Görner, K. (2018). The Possibility of Increasing Cadets' Physical Fitness Level of the Educational Organizations of the Ministry of Internal Affairs of Russia with the Help of Optimal Training Effects via CrossFit. In Journal of Physical Education and Sport, 18 (Supplement issue 5), 2022-2028. doi:10.7752/jpes.2018.s5300

Kukić, F., Jeknić, V., Dawes, J., Orr, R., Stojković, M., \& Čvorović, A. (2019). Effects of Training and a Semester Break on Physical Fitness of Police Trainees. In Kinesiology, 51(2), 161-169. doi:10.26582/k.51.2.2

Kukić, F., Koropanovski, N., Janković, R., \& Dopsaj, M. (2019). Effects of Specialized Physical Education and Additional Aerobic Training on Aerobic Endurance of Police Students. Human. Sport. Medicine, 19(S2), 58-64. doi:10.14529/hsm19s208

Lockie, R., Dawes, J., Orr, R., \& Dulla, J. (2020). Recruit Fitness Standards from a Large Law Enforcement Agency: Between-Class Comparisons, Percentile Rankings, and Implications for Physical Training. In Journal of Strength and Conditioning Research, 34(4), 934-941. doi:10.1519/JSC.0000000000003534

Losty, C., Williams, E., \& Gossman, P. (2016). Police Officer Physical Fitness to Work: A Case for Health and Fitness Training. In Journal of Human Sport \& Exercise, 11(4). 455-467.

Mackala, K., Witkowski, K., Vodičar, J., Šimenko, J., \& Stodółka, J. (2019). Acute effects of speed-jumping intervention training on selected motor ability determinants: judo vs. soccer. In Archives of Budo, 15. 311-320.

Maia, N., Kassiano, W., Assumpção, C., Andrade, A., Fernandes, R., De Jesus, K., Simim, M., \& Medeiros, A. (2019). Neuromuscular and Autonomic Responses during a CrossFit $\AA$ Competition: a Case Study. In Trends in Sport Sciences, 26(4). 165-170. doi:10.23829/TSS.2019.26.4-4

Marins, E., David, G., \& Del Vecchio, F. (2019). Characterization of the Physical Fitness of Police Officers: a Systematic Review. In Journal of Strength and Conditioning Research, 33(10), 2860-2874. doi:10.1519/JSC.0000000000003177

Osipov, A., Ratmanskaya, T., Nagovitsyn, R., Zhuikova, S., \& Iermakov, S. (2020). Increasing the Level of Cardiorespiratory and Strength Endurance of Female Students by Means of Mixed Training (Kangoo-Jumps Fitness and Resistance Training). In Physical Activity Review, 8(2), 38-47. doi:10.16926/ par.2020.08.20

Osipov, A., Kudryavtsev, M., Iermakov, S., \& Jagiełło, W. (2018). Increase in level of special physical fitness of the athletes specialising in different combat sports (judo, sambo, combat sambo) through of CrossFit training. In Archives of Budo, 14, 123-131.

Osipov, A., Kudryavtsev, M., Gatilov, K., Zhavner, T., Klimuk, Y., Ponomareva, E., Vapaeva, A., Karnaukhov, A. (2017). The Use of Functional Training - CrossFit Methods to Improve the Level of Special Training of Athletes Who Specialize in Combat Sambo. In Journal of Physical Education and Sport, 17(3), 2013-2018. doi:10.7752/jpes.2017.03201

Podstawski, R., Markowski, P., Clark, C., Choszcz, D., Ihasz, F., Stojiljković, S., \& Gronek, P. (2019). International Standards for the 3 Minute Burpee Test: High Intensity Motor Performance. In Journal of Human Kinetic, 69, 137-147. doi:10.2478/hukin-2019-0021

Pryimakov, O., Kyslenko, D., Yukhno, Y., \& Eider, E. (2019). Circular Training as a Means for Improving Physical Skills in Future Security Specialists in Higher Education Institutions of Ukraine. In Physical education of students, 23(5), 262-268. doi:10.15561/20755279.2019.0508 